\title{
Studies on Effect of Spacing on Yield and Yield Attributing Parameters of Red Cabbage (Brassica oleracea L. var. capitata f. rubra)
}

\author{
S. Manasa ${ }^{*}$ L. Mukunda Lakshmi, Syed Sadarunnisa and T. Rajasekharam \\ College of Horticulture, Anantharajupeta, Dr. Y.S.R. Horticultural University, \\ Andhra Pradesh, India \\ *Corresponding author
}

\section{A B S T R A C T}

\begin{tabular}{|c|}
\hline Keywords \\
\hline $\begin{array}{l}\text { Red cabbage, } \\
\text { Spacing, Yield } \\
\text { components, Yield }\end{array}$ \\
\hline Article Info \\
\hline $\begin{array}{l}\text { Accepted: } \\
23 \text { October } 2017 \\
\text { Available Online: } \\
\text { 10 December } 2017\end{array}$ \\
\hline
\end{tabular}

Field experiment conducted during rabi, 2017 at AICRP on Citrus, Citrus Research Station, Tirupati involved research on the effect of different plant spacings on yield and yield attributes of red cabbage. Plant density is an important variable for achieving maximum yields and uniform vegetable maturity. Optimal plant density can be achieved by establishing appropriate distances both between the rows as well as in the rows of plants. In this study, increasing the distance between plants caused an increase in number of heading leaves (19.57) with a low percentage of abnormal heads. However, there was no significant difference between different spacings regarding the number of loose leaves per plant. The most favorable parameters characterizing yield per plot $(23.80 \mathrm{~kg})$, marketable yield (183.69 q/ha) along with highest available soil N (157.47 kg/ha), P (44.36 $\mathrm{kg} / \mathrm{ha})$ and $\mathrm{K}(259.97 \mathrm{~kg} / \mathrm{ha})$ were found at closer spacing $(45 \mathrm{x} 45 \mathrm{~cm})$.

\section{Introduction}

Red cabbage (Brassica oleracea var. capitata f. rubra) is an important fancy and highly nutritive exotic vegetable. It is a biennial but grown as annual for its characteristic purple or red edible heads. It is used as salad, boiled vegetable, cooked in curries, used in pickling as well as dehydrated vegetable. It is a rich source of carotene, proteins $(0.35 \%)$, fats $(0.25 \%)$, minerals like calcium $(3.56 \%)$, phosphorus $(19.90 \%)$, potassium, sulphur etc. and vitamins viz., $A, B_{1}, B_{2}$ and $C$. Red cabbage is known to possess medicinal properties. It has an anticancer property due to the presence of indole-3-carbinol. An important advantage of red cabbage is the fact that it is generally consumed raw, which permits the preservation of vitamins sensitive to thermal processing and some polyphenolic compounds (Ismail et al., 2004). In India, cabbage including red cabbage is cultivated in an area of 388 thousand ha producing 8755 thousand MT (Anonymous, 2015-16). In Andhra Pradesh, the crops are cultivated in 5.43 thousand ha with a production of 81.45 thousand tonnes. Apart from India, red cabbage can be found throughout Northern Europe, America, and some parts of China.

Plant population studies are common features of many horticultural crops, including 
cabbage (Stoffela and Bryan, 1988). There are several citations in the literature that provide information relative to optimum plant population evaluations for cabbage that been conducted over the past 30 years (Day, 1986; Stoffela and Fleming, 1990; Lal, 1996; Stepanovic et al., 2000). Though many authors have reported some information on the plant density of different varieties of cabbage, studies regarding red cabbage are limited. Considering the above stated situations, the present study was undertaken to determine the effects of different plant and row spacing on yield and yield attributes of red cabbage.

\section{Materials and Methods}

The present investigation was undertaken to study the response of red cabbage (Brassica oleracea L. var. capitata f. rubra) to different levels of plant and row spacing. The experiment was carried out at AICRP on Citrus, Citrus Research Station, Tirupati; Andhra Pradesh during rabi, 2017 under Dr. YSR Horticultural University with the variety Red Jewel. The experiment was laid out in a factorial randomized block design with three replications.

The experimental area was divided into plots of $3.5 \mathrm{~m} \times 3.5 \mathrm{~m}$ size with an area of $12.96 \mathrm{sq}$. $\mathrm{m}$. Irrigation channels of $30 \mathrm{~cm}$ wide were provided for each row of plots. The seedlings were transplanted at a spacing of $45 \times 45 \mathrm{~cm}$, $60 \times 45 \mathrm{~cm}$ and $60 \times 60 \mathrm{~cm}$ in each plot.

To raise the crop recommended package of practices were followed. The various parameters were recorded from five randomly selected tagged plants viz., abnormal heads, number of loose leaves, and heading leaves, yield per plot, marketable yield and available $\mathrm{N}, \mathrm{P}$ and $\mathrm{K}$. The data was subjected to statistical analysis as per method suggested by Panse and Sukhatme (1967).

\section{Results and Discussion}

\begin{abstract}
Abnormal heads (\%)
Percentage of abnormal heads in red cabbage showed statistically significant variation due to the application of different levels of plant densities. Lowest percentage of abnormal heads $(9.91 \%)$ were found with the lower plant density $(60 \times 60 \mathrm{~cm})$ while, the highest percentage of abnormal heads $(12.13 \%)$ were recorded at high plant density $(45 \times 45 \mathrm{~cm})$, which was closely followed by medium plant density $(10.53 \%)$.
\end{abstract}

The abnormal head (\%) increased with a decrease in plant spacing. This can be attributed to the heavy competition between the plants that might have led to the poor uptake of nutrients and poor head growth causing the formation of abnormal heads. The trend of present results was in conformity with the findings of Indira (2012) in cauliflower.

\section{Number of loose leaves per plant}

The number of loose leaves in red cabbage was non-significant with respect to the effect of plant densities. However, maximum number of loose leaves (11.66) at lower plant density $(60 \times 60 \mathrm{~cm})$ followed by medium plant density $(60 \times 40 \mathrm{~cm})(11.11)$ and minimum number of loose leaves per plant (10.55) was found with the higher plant density $(45 \times 45 \mathrm{~cm})$.

Even though the effect of different levels of plant spacing was non-significant on the number of loose leaves per plant, different plant densities did have an effect on the number of loose leaves per plant to some extent. The number of loose leaves per plant increased with the increase in the plant spacing. These findings are in contrary with those of Hossain et al., (2011a) in cabbage. 
Int.J.Curr.Microbiol.App.Sci (2017) 6(12): 3143-3147

Table.1 Effect of different plant spacings on yield components and yield of red cabbage

\begin{tabular}{|c|c|c|c|c|c|c|c|c|}
\hline \multirow[t]{2}{*}{ Treatments } & \multirow{2}{*}{$\begin{array}{c}\text { Abnormal head } \\
(\%)\end{array}$} & \multirow{2}{*}{$\begin{array}{l}\text { Number of } \\
\text { loose } \\
\text { leaves/plant }\end{array}$} & \multirow{2}{*}{$\begin{array}{c}\text { Number of } \\
\text { heading } \\
\text { leaves/plant }\end{array}$} & \multirow{2}{*}{$\begin{array}{c}\text { Yield per plot } \\
\text { (Kg/plot) }\end{array}$} & \multirow{2}{*}{$\begin{array}{c}\text { Marketable } \\
\text { yield } \\
\text { (q/ha) }\end{array}$} & \multicolumn{3}{|c|}{ Available soil NPK (Kg/ha) } \\
\hline & & & & & & $\mathbf{N}$ & $\mathbf{P}$ & $\mathbf{K}$ \\
\hline $\mathrm{D}_{1}$ & 12.13 & 10.55 & 16.43 & 23.80 & 183.69 & 129.73 & 37.12 & 191.16 \\
\hline $\mathrm{D}_{2}$ & 10.53 & 11.11 & 18.59 & 19.87 & 153.29 & 150.81 & 39.89 & 225.85 \\
\hline $\mathrm{D}_{3}$ & 9.91 & 11.66 & 19.56 & 16.23 & 125.21 & 157.47 & 44.36 & 259.97 \\
\hline S.Em \pm & 0.140 & 0.316 & 0.155 & 0.077 & 0.783 & 0.669 & 0.180 & 0.301 \\
\hline C.D $(P=0.05)$ & 0.420 & N.S* & 0.466 & 0.232 & 2.350 & 2.006 & 0.540 & 0.902 \\
\hline
\end{tabular}

Plot size: 12.96 sq. m.

* N.S. - Non-significant

$\mathrm{D}_{1}$ : High density $(45 \mathrm{~cm} \times 45 \mathrm{~cm})(49,383$ plants/ha)

$\mathrm{D}_{2}:$ Medium density $(60 \mathrm{~cm}$ x $45 \mathrm{~cm})(37,037$ plants/ha)

$\mathrm{D}_{3}$ : Low density $(60 \mathrm{~cm}$ x $60 \mathrm{~cm})(27,778$ plants/ha $)$ 


\section{Number of heading leaves per plant}

The number of heading leaves in red cabbage was significant with respect to the effect of plant densities. The maximum number of heading leaves (19.56) at lower plant density $(60 \times 60 \mathrm{~cm})$ followed by medium plant density $(60 \times 45 \mathrm{~cm})(18.59)$ and minimum number of heading leaves per plant (16.43) was found with the higher plant density $(45 \times 45 \mathrm{~cm})$. Higher plant density resulted in maximum number of heading leaves per plant in red cabbage. The plants grown under wider spacing received more nutrients, light and moisture around compared to plants of closer spacing, which was probably the cause of better performance in yield attributes like number of heading leaves per plant. These findings are in line with Moniruzzaman (2011) in cabbage.

\section{Yield per plot}

There was a prominent effect of different spacings on yield of red cabbage. Significantly highest yield per plot $(23.80 \mathrm{~kg} / 12.96$ sq.m.) was recorded with the higher plant density $(45 \times$ $45 \mathrm{~cm}$ ) which was statistically similar to medium plant density $(60 \times 45 \mathrm{~cm})$ (19.87kg/12.96 sq.m.). Lowest yield (16.23 $\mathrm{kg} / 12.96$ sq.m.) was recorded with lower plant density $(60 \times 60 \mathrm{~cm})$. The maximum yield per plot was found superior at higher plant density which was possibly due to more number of plants per unit area; higher ground covers of leaf area resulted in higher light interception and hence, higher assimilate production. Similar results have been reported by Sharma and Chaudhary (1996) in cauliflower and Agarwal et al., (2007) in broccoli.

\section{Marketable yield}

Different levels of nitrogen application and spacing significantly influenced marketable yield of red cabbage. Highest yield (183.69 $\mathrm{q} / \mathrm{ha}$ ) was recorded with the higher plant density $(45 \times 45 \mathrm{~cm})$ followed by the medium plant density $(60 \times 45 \mathrm{~cm})(153.29 \mathrm{q} / \mathrm{ha})$ while, minimum yield $(125.21 \mathrm{q} / \mathrm{ha})$ was recorded with lower plant density $(60 \times 60 \mathrm{~cm})$. The maximum marketable yield was found superior at higher plant density due to more number of plants per unit area; higher ground covers of leaf area resulted in higher assimilates production. Moniruzzaman (2011) conducted a field experiment on cabbage (Brassica oleracea var. capitata) comprising two plant spacings i.e. $60 \times 40 \mathrm{~cm}$ and $60 \times 45 \mathrm{~cm}$ and his results indicated that highest marketable head yield (73.32 t/ha) was produced in $\mathrm{K}-\mathrm{K}$ Cross cultivar at a spacing of $60 \times 40 \mathrm{~cm}$. Sanderson and Fillmore (2010) achieved the highest marketable yield in broccoli at 5.56 plants $/ \mathrm{m}^{2}$ in a single row with $90 \mathrm{~cm}$ between the row and $20 \mathrm{~cm}$ within the row. Singh and Naik (1988) observed that closest spacing of $45 \times 30 \mathrm{~cm}$ produced significantly higher number of marketable heads resulting in higher marketable yield/ha in cabbage, however, maximum head weight/plant was found in the widest spacing of $60 \times 45 \mathrm{~cm}$. Similar results have been reported by Agarwal et al., (2007) in broccoli.

\section{Available soil NPK}

Different planting densities significantly influenced the available soil nitrogen, phosphorus and potassium in red cabbage. The data regarding the effect of plant densities on available soil NPK are presented in Table 1. The available soil nitrogen was significantly higher with $60 \times 60 \mathrm{~cm}(157.47 \mathrm{~kg} / \mathrm{ha})$ followed by $60 \times 45 \mathrm{~cm}$ with $150.81 \mathrm{~kg} / \mathrm{ha}$ and lower available soil nitrogen (129.73 kg/ha) was recorded with $45 \times 45 \mathrm{~cm}$. Available soil phosphorus in soil was found to be highest at 60 $\times 60 \mathrm{~cm}(44.36 \mathrm{~kg} / \mathrm{ha})$ and lowest at $45 \times 45 \mathrm{~cm}$ $(37.12 \mathrm{~kg} / \mathrm{ha})$. Highest available soil potassium $(259.97 \mathrm{~kg} / \mathrm{ha})$ was recorded with $60 \times 60 \mathrm{~cm}$ followed by $60 \times 45 \mathrm{~cm}(225.85 \mathrm{~kg} / \mathrm{ha})$ and the lowest soil potassium content $(191.16 \mathrm{~kg} / \mathrm{ha})$ was recorded by $45 \times 45 \mathrm{~cm}$. This may be attributed to the nature of nitrogen which governs the availability and utilization of soil phosphorus, potassium and other constituents to a considerable degree. These results were in agreement with the findings of Lavanya (2014) in cabbage. 
Red cabbage cv. Red Jewel was evaluated for the best combination of planting spacing for obtaining highest yield and yield attributes. At the lowest spacing treatment the yield of red cabbage is highest. Therefore, we can conclude that plant at closer space growth yields more due to more number of plants per unit area. On the other hand, closer plant spacing didn't increase the yield attributes like number of loose leaves, number of heading leaves, abnormal head (\%) etc., The yield attributes along with available soil nitrogen, phosphorus and potassium were observed to be maximum with wider spacing.

\section{References}

Agarwal, A, Gupta, S. and Ahmed, Z. 2007. Nitrogen nutrition and plant density influencing marketable head yield of broccoli in cold arid desert of Ladakh. Acta Horticulture. 756: 299 - 307.

Anonymous, 2015-16. National Horticulture Mission, Government of India.

Day, M.J. 1986. A comparison of yield and quality factors in two winter white cabbage cultivars at five population. Journal of the National Institute of Agricultural Botany. 17 (2): 231244.

Hossain, D, Haque, M.A, Abuyusuf, M, Riad, M.M. and Hussain, A.S.M. 2011a. Response of cabbage to different levels of fertilizer application in salna silty clay loam soil. Bangladesh Research Publications Journal. 6(2): 155-166.

Indira, K. 2012. Studies on the effect of plant densities and nitrogen levels on growth and curd yield of cauliflower (Brassica oleracea var. botrytis L.) cv. Pusa Sharad. M.Sc. thesis submitted to Dr. YSR. Horticultural University, Venkataramannagudem.

Ismail, A, Marjan, Z.M. and Foong Ch.W. 2004. Total antioxidant activity and phenolic content in selected vegetables. Food
Chemistry. 87: 581-586.

Lal, G. 1996. Effect of nitrogen and spacing on yield and quality of cabbage (Brassica oleracea $L$. var. capitata). Annals of Biology. 12 (2): 242244.

Lavanya, P. 2014. Effect of dates of planting and nitrogen on growth and yield of cabbage (Brassica oleracea var. capitata. L.). M.Sc. thesis submitted to Dr. YSR. Horticultural University, Venkataramannagudem.

Moniruzzaman, M. 2011. Effect of plant spacings on the performance of hybrid cabbage (Brassica oleracea var. capitata) varieties. Bangladesh Journal of Research. 36(3): 495-506.

Panse, M. and Sukhatme, K. 1985. Statistical methods for agriculture workers. Indian Council of Agriculture Research Publications. 48-67.

Sanderson, K.R. and Fillmore, S.A.E. 2010. Response of broccoli (Brassica oleracea $L$. var. italica) yield and hollow stem to plant density, tickle irrigation and transplanting date. Canadian Journal of Plant Sciences. 90 (5): $729-735$.

Sharma, D.K. and Chaudhary, D.R. 1996. Time of sowing and plant density on growth and curd yield in early cauliflower (Brassica oleracea L. var. botrytis) cv. Early Kunwari. Vegetable Science. 23 (2): 141 - 144.

Singh, R.V. and Naik, L.B. 1988. Response of cabbage to plant spacing, nitrogen and phosphorus levels. Indian Journal of Horticulture. 45 (3-4): 325- 328.

Stepanovic, M.V, Bjelic, V.V, Dragicevic, V.D. 2000. Effect of crop density on morphological characteristics and yield of cabbage. Acta Horticulture. 533: 205-207.

Stoffela, P.J, Bryan, H.H. 1988. Plant population influences growth and yield of bell pepper. Journal of American Society for Horticultural Science. 113: 835-839.

Stoffela, P.J, Fleming, M.F. 1990. Plant population influences yield variability of cabbage. Journal of American Society for Horticultural Science. 115, 5: 708-711.

\section{How to cite this article:}

Manasa, S., L. Mukunda Lakshmi, Syed Sadarunnisa and Rajasekharam, T. 2017. Studies on Effect of Spacing on Yield and Yield Attributing Parameters of Red Cabbage (Brassica oleracea L. var. capitata f. rubra). Int.J.Curr.Microbiol.App.Sci. 6(12): 3143-3147.

doi: https://doi.org/10.20546/ijcmas.2017.612.366 